\title{
Systems Thinking and Shared Vision and Mission as Determinants of Organizational Learning Capabilities (OLC) in Academic Library
}

\author{
Mohd Shamsul Mohd Shoid and Norliya Ahmad Kassim
}

Faculty of Information Management, Universiti Teknologi MARA (UiTM) Shah Alam, Malaysia

\begin{abstract}
This study aims to examine the perceptions regarding systems thinking and shared vision and mission of librarians in an academic library in Malaysia. In this preliminary study, questionnaires were distributed to fifty academic librarians in one large public university in Malaysia. The result shows that respondents' perception on shared vision and mission, systems thinking and knowledge performance are very similar and moderately positive. In addition, a strong relationship exists between shared vision and mission and systems thinking. Shared vision and mission has a higher correlation with knowledge performance than systems thinking. The result also shows that there are no differences in the perceptions between males and females, middle and senior management as well as between those with bachelor degree and master qualifications. The outcome of the study is expected to lead librarians to improve the skills to acquire knowledge and learning capabilities for better knowledge performance in the academic library.
\end{abstract}

Keywords: shared vision and mission, systems thinking, organizational learning capabilities (OLC), academic library.

\section{Introduction}

Knowledge and learning as a key resource will contribute to improve knowledge performance if it is properly leveraged and harnessed. Organizational learning works like a catalyst to push forward the organization in a holistic way. Organizational learning leads to enhance productivity and performance measured through tangible and non-intangible variables. The concept of organizational learning capabilities (OLC) has been dealt with extensively in the literature and has generated many academic publications both in specialized journals and those of a more general scope. Libraries in higher learning institutions are now connected to the knowledge society which tries to make clear on how to use the knowledge in order to achieve its interest as well as to manage the streams of information. Moreover, both learning and knowledge are important resources of the organization which remain and give competitive advantages. The existence of learning and knowledge will create and define the true concept of knowledge management process through knowledge acquisition and organizational learning capabilities at libraries in the higher learning institutions. The increased capacity of identifying, distilling, harnessing and using information will help to construct knowledge for the organizational learning practices to become more effective.

Librarians in organizations such as academic libraries are specialized in knowledge management process. They work in three areas which are user services, the task of administrative services and technical services. However, nowadays, their tasks have been challenged by increasingly complex and constant change in the organizational, technological and information environment. Librarians need to stay update with new technologies and 
systems, new forms of information, information media and information sources, tasks and roles. Indeed, the main role of libraries in higher learning institutions is to nurture and instil necessary higher learning skills and knowledge capabilities among individuals or group by presenting existing or creating new knowledge (Rowley, 2000; Mohd Shamsul et al., 2011).

Besides, the merits and performance of the librarians are depending on the efforts to learn and upgrade the new skills that have been required by the parent institution. Hence, it is important to be familiar with the complex of social, political and cultural environment of the institutions especially the higher learning institutions. Apart from this, librarians are responsible to assist the library patrons with the loan and return, Internet usage in searching the quality information, planning and management of libraries, technical services, acquisitions and cataloguing, indexing and abstracting.

Given the above factors, this preliminary study aims to investigate the perceptions on organizational learning capabilities (OLC) and knowledge performance of librarians in an academic library. This paper addresses two dimensions of the OLC which are: shared vision and mission and systems thinking. The objectives are:-

1. To examine the perceptions of librarians on shared vision and mission, systems thinking and knowledge performance.

2. To determine the relationships between OLC's dimensions:-

3. To determine the relationships between OLC's dimensions and knowledge performance:-

4. To compare mean difference on OLC dimensions between gender, position and education level.

\section{Literature Review}

\section{Organizational Learning Capabilities (OLC)}

Organizational learning or organizational learning capability is about the ability of one organization in order to apply the accurate and appropriate management practices, its structures as well as the procedures which enhance, facilitate and encourage learning (Goh, 2003). Goh (2003) added that the growth of this practice will result in stronger learning capability throughout the organization. On the other hand, Sayyed, Somaye and Sayyed (2010) stated that OLC are the organizational and managerial factors which contribute to the enhancement of organizational learning process in organization. Furthermore, by listing down the failures, organization will examine the beneficial and non-beneficial success and errors for future use. Thus, knowledge management and organizational learning benefit in various aspects of organizational life such as quality management and information systems, to finance and export management. Such various aspects have extended with distinct views which reveal the opinions and interest from various points. All views may have different values, therefore perceptions and some focus are needed, so that practitioners and academia can accept the practice and theory and also help the disciplines to move further (Kit and Nathai-Balkisson, 2011; Abdullah and Norliya, 2008).

\section{Systems Thinking}

Systems thinking is a system that provides the understanding of organization's original business and problems in the business. By viewing and understanding organization's original business and determining the problem caused, leaders and other staff will collaborate with each other in order to find the better solution for 
the organization. Employees, who implement systems thinking in identifying personal values in the organizations, will be able to find solutions for organizational problems and develop strategic plans for organizational sustainability. These positive influences may help to improve their organizational learning skills (Senge, 1990). Meanwhile, Poon and Kamarul Zaman, (1998) further see that systems thinking framework builds the understanding among the employees regarding the interrelationships of key components of systems that run in the organization.

\section{Shared Vision and Mission}

Shared vision is a well-accepted mission in a library's context. It encourages the librarians to generate and contribute to the aspiration by satisfying and fulfilling the information needs among the users. In order to promote sharing knowledge among employees, Lopez et al. (2005) believe that the employer should set up goals of achievements of each project as well as share the vision of the organization. Therefore, the products and services provided are at a higher level and the organization's business is expanded. According to Senge et al. (1990), shared vision is about developing sense of commitment in organization by designing the future images of principle and ambition as a guide to success. Determining the clarity of vision and mission in an organization is important in order to prevent the lack of performance of the organisation itself (Hishamuddin et al., 2010). On their part, Pearce and David (1987) and Calantone et al. (2002) elicit that shared vision and mission help in generating the optimistic performance of organizations in terms of financial subject.

\section{Knowledge Performance}

Selden (1998), Abdullah and Norliya (2010) and Norliya (2010) mentioned that knowledge performance is about the ability of individuals, teams and organizations to understand what they have learned. Knowledge is sustainable and it has been divided into four subsystems including acquisition, creation, storage and transfer. The management of knowledge is vital as it is the centre or the heart of organizational learning. Human is the vital carrier agent of knowledge awareness or knowledge understanding. Learning organization that engages with knowledge is always growing and developing by not having to destroy the knowledge capital of organization. There is a vast difference between the mindset of an organization with learning and knowledge development and organizations that have short-term competence and productivity with single aims (Marsick and Watkinson, 1999).

On the other hand, organizational learning capabilities are expected to improve and enhance organizational performance (Marshall, Smith and Buxton, 2009). The entire spectrum of literature examined the process, systems and factors that facilitate the performance of the organization. Most of the literatures are likely to be rigid, appear with multiple formats and exist with an ideal set of learning environment. Furthermore, Field (2011) suggests few aspects of organizational learning which involve employees in technical and economic interest, human experience and social activity around the communication, achieving consensus, practical interest, freedom, autonomy and responsibility including maintaining freedom, power adjustment and systems of beliefs. However, the most important thing is to understand the fundamental tensions between commercial interest (money and power). Besides, literature of organizational learning should be more sensitive on management effort on learning. Shared learning throughout the organization should not only focus on product delivery and services, but also on negotiations and performance management which play an important role in organizational effectiveness (Norliya and Abdullah, 2012).

\section{Methodology}

This study employs a quantitative approach method. In this preliminary study, questionnaires were personally distributed to fifty selected librarians who 
work in an academic library in one large public university in Malaysia. Only thirtysix questionnaires were returned and were usable for analysis. In order to ensure measurement reliability, items in the questionnaire were adapted from previous studies which have been modified by the researchers after synthesizing several studies in the field of OLC and knowledge performance. Prior to formal data collection, twenty-nine items of the questions which contained relevant variables of OLC and knowledge performance were gathered from the literature review as well as previous measures. They were then presented to a selected panel of experts which consists of experts and OLC practitioners for the purpose of establishing content validity of the instrument. The questionnaire was designed on a 1 (strongly disagree) through 7 (strongly agree) Likert scale. Descriptive and inferential statistical analyses were performed to analyze the data.

\section{Results and Discussions}

\section{Reliability Analysis}

The three variables of interest in this study are measured by the respective aggregated mean of items. The number of items for each variable ranges from 7 to 14 (Table 1). The reliability test results indicate that systems thinking (0.912), shared vision mission (0.876) and knowledge performance (0.964) have a high internal consistency, thus satisfying the validity assumption of the items in the respective dimensions.

Table 1: Results of Reliability Test

\begin{tabular}{|c|l|c|c|}
\hline No. & \multicolumn{1}{|c|}{ Variables } & Cronbach's Alpha & No. of Items \\
\hline 1 & Systems Thinking & 0.912 & 8 \\
\hline 2 & Shared Vision and Mission & 0.876 & 7 \\
\hline 3 & Knowledge Performance & 0.964 & 14 \\
\hline
\end{tabular}

\section{Profile of Respondents}

The summary statistics for the profile of the 36 respondents are presented in Table 2. The sample was made up of two-thirds of females $(66.7 \%)$ and one-third males $(33.3 \%)$, a large proportion of middle management staff $(88.9 \%)$ compared with senior management staff $(11.1 \%)$ and a slightly higher proportion of a bachelor degree holders $(58.3 \%)$ compared with a master's degree holders (41.7\%). Figure 1 shows that among the females, three $(12.5 \%)$ were senior management staff compared with only one among the males (8.3\%). There was also a relatively higher proportion of females with a master's degree $(45.8 \%)$ compared with their male counterparts $(33.3 \%)$.

Table 2: Summary of Respondents Profile

\begin{tabular}{|l|l|c|c|}
\hline \multicolumn{1}{|c|}{ Variable } & \multicolumn{1}{|c|}{ Category } & $\begin{array}{c}\text { Number of } \\
\text { Respondents }\end{array}$ & $\begin{array}{c}\text { Percent of } \\
\text { Sample (\%) }\end{array}$ \\
\hline \multirow{2}{*}{ Gender } & Male & 12 & 33.3 \\
\cline { 2 - 4 } & Female & 24 & 66.7 \\
\hline \multirow{2}{*}{ Position } & Senior management & 4 & 11.1 \\
\cline { 2 - 4 } & Middle management & 32 & 88.9 \\
\hline \multirow{2}{*}{ Education level } & Bachelor degree & 21 & 58.3 \\
\cline { 2 - 4 } & Master degree & 15 & 41.7 \\
\hline
\end{tabular}




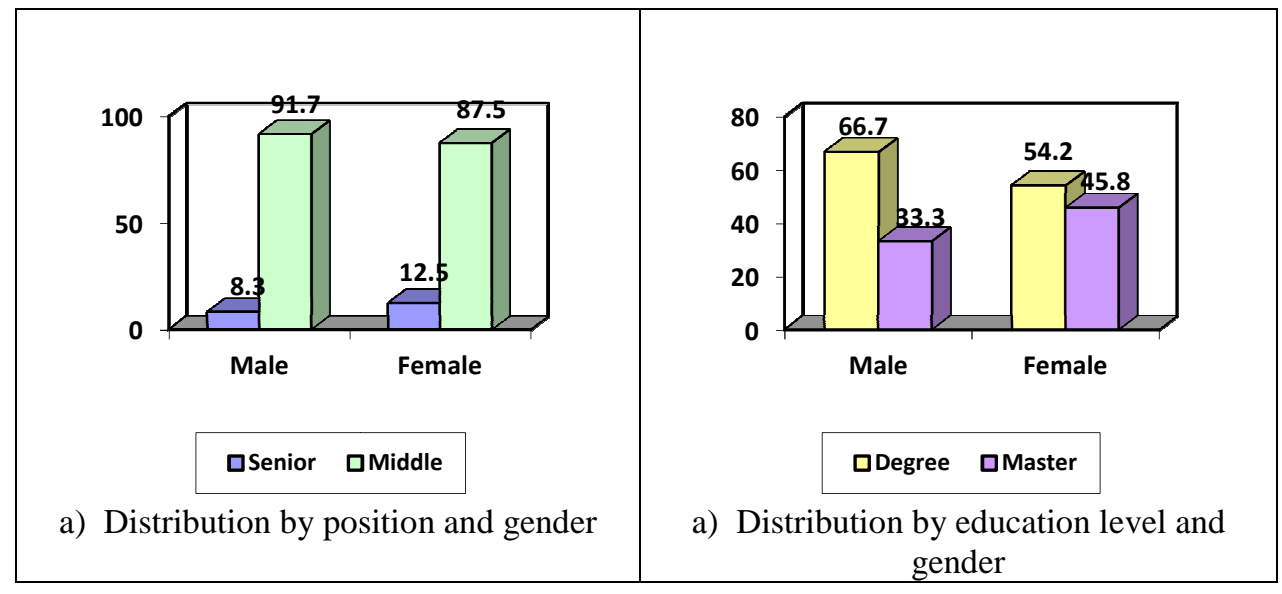

Figure 1: Comparison of Gender Distribution by Position and Education Level

\section{Normality Test}

Table 3 contains the results of the ShapiroWilk test for normality which show that shared vision and mission, systems thinking and knowledge performance are normally distributed, thus justifying the use of parametric methods for the analysis. However, due to the small sample size, non-parametric test was used to compare the mean difference on the OLC dimensions between gender, position and education level.

Table 3: Results of Normality Test

\begin{tabular}{|l|c|c|c|}
\hline \multirow{2}{*}{} & \multicolumn{3}{|c|}{ Shapiro-Wilk } \\
\cline { 2 - 4 } & Test Statistic & df & p-value \\
\hline Shared vision mission & 0.970 & 36 & 0.424 \\
\hline Systems thinking & 0.970 & 36 & 0.424 \\
\hline Knowledge performance & 0.982 & 36 & 0.806 \\
\hline
\end{tabular}

\section{Perceptions of OLC and Knowledge} Performance

As mentioned earlier, the respective dimension is measured by the aggregated mean of the 7-point Likert scale items (Table 4).The results show that on the average, the perception of the respondents on the three dimensions are very similar and moderately positive as they fall within a very short range of between 5.53 and 5.74. Shared vision and mission has the highest score (5.74), followed by knowledge performance (5.72) and systems thinking (5.53).

\section{Table 4: Ranking of the Level of Perception}

\begin{tabular}{|c|l|c|c|}
\hline No. & \multicolumn{1}{|c|}{ Dimension } & Mean Score & $\begin{array}{c}\text { Standard } \\
\text { Deviation }\end{array}$ \\
\hline 1 & Shared Vision and Mission & $5.74^{*}$ & 0.554 \\
\hline 2 & Knowledge Performance & 5.72 & 0.457 \\
\hline 3 & Systems Thinking & 5.53 & 0.496 \\
\hline
\end{tabular}

* The higher the mean score, the more positive is the perception 


\section{Perceptions on Shared Vision and Mission}

Table 5 shows the mean scores of perceptions on shared vision and mission statements. On the average, the respondents were moderately positive towards their organization's shared vision and mission. The mean scores of the seven individual items are very similar, ranging from 5.63 (Staff and clients encourage comments and complaints to do better job) to 5.83 (Organization's vision is understood and accepted by employees), hence, also indicating a moderate positive perception towards their organization's vision and mission.

Table 5: Results of Mean Score by Shared Vision and Mission

\begin{tabular}{|l|c|c|}
\hline Shared Vision and Mission: In my library & Mean & Std Deviation \\
\hline $\begin{array}{l}\text { Organization's vision is understood and accepted by } \\
\text { employees }\end{array}$ & 5.83 & 0.654 \\
\hline $\begin{array}{l}\text { Organization's vision and mission is clearly shown and } \\
\text { highly supported by employees }\end{array}$ & 5.80 & 0.787 \\
\hline $\begin{array}{l}\text { Higher level management and employees shared the } \\
\text { organization's vision towards work accomplishment }\end{array}$ & 5.78 & 0.710 \\
\hline $\begin{array}{l}\text { New ideas from the staff team is most welcomed by the } \\
\text { higher management }\end{array}$ & 5.67 & 0.797 \\
\hline $\begin{array}{l}\text { Opportunities are provided to each employee in order to } \\
\text { achieve goal }\end{array}$ & 5.67 & 0.756 \\
\hline $\begin{array}{l}\text { Higher management and employees are sharing the } \\
\text { common vision of organization's main business }\end{array}$ & 5.63 & 0.640 \\
\hline $\begin{array}{l}\text { Staff and clients encourage comments and complaints to } \\
\text { do better job }\end{array}$ & 5.74 & 0.554 \\
\hline
\end{tabular}

\section{Perceptions on Systems Thinking}

The mean scores in Table 6 also indicate that on the average the respondents have moderately positive perception towards the systems thinking, but with a slightly lower score than those of vision and mission. Among the eight statements, the respondents were most positive (5.78) that employees recognize that the library is a part of larger system but least positive that employees are encouraged to engage and respond to each of the decision and action made by the organization (5.41). Most also agree that that they have advance systems which allow them to learn best practice of other organization (mean $=5.69$ ), and employees are informed of how their role contributes to the whole organizational process (5.61). The rest of the items were scored lower, between 5.41 and 5.58, indicating a less positive perception. 
Table 6: Results of Mean Score by Systems Thinking

\begin{tabular}{|l|c|c|}
\hline \multicolumn{1}{|c|}{ Systems Thinking: In my library } & Mean & $\begin{array}{c}\text { Std } \\
\text { Deviation }\end{array}$ \\
\hline $\begin{array}{l}\text { Employees recognize that the library is a part of larger } \\
\text { systems }\end{array}$ & 5.78 & 0.760 \\
\hline $\begin{array}{l}\text { We do have the advanced system which allows us to } \\
\text { learn best practices of other organizations }\end{array}$ & 5.69 & 0.920 \\
\hline $\begin{array}{l}\text { Employees are informed of how their role contributes } \\
\text { to the whole organizational process }\end{array}$ & 5.61 & 0.803 \\
\hline $\begin{array}{l}\text { Employees are advised to understand the perspectives } \\
\text { of different employee in other position }\end{array}$ & 5.58 & 0.732 \\
\hline $\begin{array}{l}\text { Employees should view an organization made up of } \\
\text { different departments as one integrated system }\end{array}$ & 5.58 & 0.732 \\
\hline $\begin{array}{l}\text { All employees should focus dynamic thinking towards } \\
\text { the organization's performance }\end{array}$ & 5.58 & 0.692 \\
\hline $\begin{array}{l}\text { Employee s are encouraged to form informal groups to } \\
\text { solve organizational problems and provide best } \\
\text { solutions for benchmarking }\end{array}$ & 5.44 & 0.734 \\
\hline $\begin{array}{l}\text { Employees are encouraged to engage and respond to } \\
\text { each of the decision and action made by the } \\
\text { organization }\end{array}$ & 5.41 & 0.496 \\
\hline
\end{tabular}

\section{Perceptions on Knowledge Performance}

Table 7 exhibits the mean scores of perceptions by respondents on knowledge performance. On the average the respondents were more positive towards knowledge performance (5.72) than systems thinking 5.53), but very similar to shared vision and mission (5.74). However, further analysis on the individual items reveals that the respondents were more positive towards knowledge performance in their libraries than the other dimensions. Specifically, more respondents perceived that feedback from clients helped to improve services (5.94), information skills program helped to determine user satisfaction (5.89) and librarians exchanged knowledge inside and outside the organization (5.86). 
Table 7: Results of Mean Score by Knowledge Performance

\begin{tabular}{|l|c|c|}
\hline Knowledge Performance: In my library & Mean & $\begin{array}{c}\text { Std } \\
\text { Deviation }\end{array}$ \\
\hline Feedback from clients helps to improve services & 5.94 & 0.630 \\
\hline $\begin{array}{l}\text { Information skills program helps to determine user } \\
\text { satisfaction }\end{array}$ & 5.89 & 0.708 \\
\hline $\begin{array}{l}\text { Librarians exchanged knowledge inside and outside the } \\
\text { organization }\end{array}$ & 5.86 & 0.639 \\
\hline Specific skills are needed for future tasks & 5.75 & 0.692 \\
\hline $\begin{array}{l}\text { Knowledge is improved and skills are updated in order to } \\
\text { achieve organization's vision and mission }\end{array}$ & 5.75 & 0.649 \\
\hline Knowledge on new materials is acquired & 5.72 & 0.615 \\
\hline $\begin{array}{l}\text { Embedding knowledge such as planning, design and service } \\
\text { are practiced }\end{array}$ & 5.72 & 0.513 \\
\hline Information about external clients is gathered & 5.70 & 0.577 \\
\hline $\begin{array}{l}\text { Enhancement of knowledge and skills give benefits to the } \\
\text { organization }\end{array}$ & 5.69 & 0.525 \\
\hline Existing knowledge helps to generate new information & 5.67 & 0.632 \\
\hline Effective knowledge is acquire and been sharing with others & 5.64 & 0.723 \\
\hline Employees' competencies in solving problems are needed & 5.61 & 0.688 \\
\hline The number of users learning new skills is increasing & 5.61 & 0.599 \\
\hline \begin{tabular}{l} 
14. Knowledge about internal clients is acquired \\
\hline Overall
\end{tabular} & 5.56 & 0.939 \\
\hline
\end{tabular}

\section{Relationships between OLC Dimensions and Knowledge Performance}

The results of the Pearson's coefficient correlation test (Table 8) show that systems thinking was strongly correlated with shared vision and mission $(p<0.01, r$
$=0.773$ ). However, the correlation between knowledge performance and shared vision mission ( $p<0.01, r=0.513)$, as well as systems thinking and knowledge performance $(p<0.01, r=0.491)$ are much lower but also significant $(\mathrm{p}<0.001)$.

Table 8: Pearson Coefficient Correlation Analysis

\begin{tabular}{|c|c|c|c|}
\hline Statistics & SVM & ST & KP \\
\hline $\begin{array}{l}\text { Shared vision and mission(SVM) Pearson } \\
\text { Correlation } \\
\qquad \text { Sig. (2-tailed) }\end{array}$ & 1.000 & $\begin{array}{l}0.773^{* *} \\
<0.001\end{array}$ & $\begin{array}{r}0.513^{* *} \\
0.001\end{array}$ \\
\hline $\begin{array}{lc}\begin{array}{l}\text { Systems thinking (ST) } \\
\text { Correlation }\end{array} & \text { Pearson } \\
& \text { Sig. (2-tailed) } \\
\end{array}$ & $\begin{array}{l}0.773^{* *} \\
.<0.001\end{array}$ & 1.000 & $\begin{array}{r}0.491^{* *} \\
0.001\end{array}$ \\
\hline $\begin{array}{l}\text { Knowledge performance (KP) Pearson } \\
\text { Correlation } \\
\qquad \text { Sig. (2-tailed) }\end{array}$ & $\begin{array}{c}0.513^{* *} \\
0.001\end{array}$ & $\begin{array}{r}0.491^{* *} \\
0.001\end{array}$ & 1.000 \\
\hline
\end{tabular}

\section{Comparison of Perceptions towards OLC Dimensions between Gender, Position and Education Level}

Table 9 presents the Mann-Whitney U test to compare the perception towards shared vision and mission by selected variables. Since the sample size is small, non- parametric test was used for the analysis. There was no evidence of gender difference in their perception towards this dimension. Similarly, there was no evidence of differences in perceptions between middle and senior management respondents as well as between those with first degree and master degree qualifications. 
Table 9: Results of Mann-Whitney U Tests for Shared Vision and Mission

\begin{tabular}{|c|c|c|c|c|c|}
\hline Variable & Category & Mean Rank & $\begin{array}{c}\text { Mann-Whitney } \\
\text { U Statistic }\end{array}$ & Z-value & $p$-value \\
\hline \multirow{2}{*}{ Gender } & Male & 22.38 & \multirow{2}{*}{97.500} & \multirow{2}{*}{1.571} & \multirow{2}{*}{0.116} \\
\hline & Female & 16.56 & & & \\
\hline \multirow{2}{*}{ Position } & $\begin{array}{c}\text { Middle } \\
\text { Management }\end{array}$ & 21.75 & \multirow{2}{*}{51.000} & \multirow{2}{*}{-0.659} & \multirow{2}{*}{0.510} \\
\hline & $\begin{array}{c}\text { Senior } \\
\text { Management }\end{array}$ & 18.09 & & & \\
\hline \multirow{2}{*}{$\begin{array}{l}\text { Education } \\
\text { Level }\end{array}$} & Bachelor degree & 18.43 & \multirow{2}{*}{156.000} & \multirow{2}{*}{-0.048} & \multirow{2}{*}{0.961} \\
\hline & Master degree & 18.60 & & & \\
\hline
\end{tabular}

Comparison of Perceptions towards OLC Dimensions between Gender, Position and Education Level

Similar results were also obtained for their perception towards systems thinking (see
Table 10). Therefore, based on the preliminary study results, there is no evidence that perceptions are associated with the respondents' background.

Table 10: Results of Mann-Whitney U Tests for Systems Thinking

\begin{tabular}{|c|c|c|c|c|c|}
\hline Variable & Category & $\begin{array}{c}\text { Mean } \\
\text { rank } \\
\end{array}$ & $\begin{array}{c}\text { Mann-Whitney } \\
\text { U Statistic }\end{array}$ & z-value & $p$-value \\
\hline \multirow{2}{*}{ Gender } & Male & 21.67 & \multirow{2}{*}{106.00} & \multirow{2}{*}{1.284} & \multirow{2}{*}{0.199} \\
\hline & Female & 16.92 & & & \\
\hline \multirow{2}{*}{ Position } & $\begin{array}{c}\text { Middle } \\
\text { Management }\end{array}$ & 26.75 & \multirow{2}{*}{31.000} & \multirow{2}{*}{-1.673} & \multirow{2}{*}{0.094} \\
\hline & $\begin{array}{c}\text { Senior } \\
\text { Management }\end{array}$ & 17.47 & & & \\
\hline \multirow{2}{*}{$\begin{array}{l}\text { Education } \\
\text { Level }\end{array}$} & $\begin{array}{c}\text { Bachelor } \\
\text { degree }\end{array}$ & 18.19 & \multirow[t]{2}{*}{151.000} & \multirow[t]{2}{*}{-0.210} & \multirow[t]{2}{*}{0.834} \\
\hline & Master degree & 18.93 & & & \\
\hline
\end{tabular}

\section{Conclusions}

The results indicate a strong relationship between shared vision mission and systems thinking. Between the two OLC dimensions, shared vision and mission has a higher correlation with knowledge performance than systems thinking. Also, the results do not identify any differences in perceptions between males and females, middle and senior management as well as between those with bachelor degree and master degree qualifications. Since this study was based on data from only one university library, the results should not be generalised to other libraries. Future studies should use a representative sample with respondents randomly selected from the targeted population of academic librarians. The instrument should also include more OLC dimensions such as transfer of knowledge, leadership and other knowledge performance measurements. Learning and knowledge are also important elements of an effective organization as well as a tool for knowledge accumulation for librarians in academic libraries. Therefore, these positive results of librarian's perceptions on OLC are an indication of the right path towards a better performance, as well as a catalyst for further research in library and information science. The results will define the learning capability and assist organization in making appropriate adjustments to improve organizational performance effectiveness and competitiveness. The outcome of the study is thus useful in identifying appropriate programs to improve the skill of acquiring knowledge and enhance the learning 
capabilities of librarians and library staff in academic libraries.

\section{Acknowledgment}

This research was supported by Universiti Teknologi MARA (UiTM), Shah Alam, Selangor, Malaysia. The authors wish to thank UiTM and all respondents who had participated in this research.

\section{References}

Abdullah, K. A. S. (2010). Organizational Learning in Learning Organization, Shah Alam: University Publication Center, UITM.

Abdullah, K. A. S. \& Kassim, N. A. (2008). "Perceptions of Organisational Learning Practices among Yemeni University Librarians," Malaysia Journal of Library and Information Science, 3(1), 77-90.

Allameh, S. M., Abbasi, S. \& Shokrani, S. A. R. (2010). "The Mediating Role of Organisational Learning Capability between Intellectual Capital and Job Satisfaction," European Journal of Social Sciences, 17(1), 125-136.

Calantone R. J., Cavusgil, S. T. \& Zhao, Y. (2002). "Learning Orientation: Firm Innovation Capability and Firm Performance," Industrial Marking Management, 31(4), 515-524.

Field, L. (2011). "Exploring the Political Underbelly of Organisational Learning: Learning During Pay and Performance Management Change," The Learning Organisation, 18(41), 272-287.

Goh, S. C. (2003). "Improving Organisational Learning Capability: Lesson from Two Case Studies," The Learning Organization, 10(4), 216-227.

Hishamudin Md. Som, Mohamad Nasir Saludin, Md. Shukri Shuib, Mohamad Faisol Keling, Mohd Na'eim Ajis \& Roland Yeow Theng Nam (2010). "Learning Organisation Elements as Determinants of Organizational Performance of Non-profit Organisations (NPOs) in Singapore," International NGO Journal, 5(5), 117-128.
Kassim, N. A. (2010). Learning Organization: Multiple Papers as Research Outcome, Shah Alam: University Publication Center, UiTM.

Kit, F. P. \& Nathai-Balkisson, M. (2011). "Integrating Knowledge Management into Organisational Learning: A Review Concepts and Models," The Learning Organisation, 18(3), 203-223.

Lopez, S. P., Peon, J. M. M., Ordas, C. J. V. (2005). "Human Resources Practices, Organisational Learning and Business Performance," Human Resources Development International, 8(2), 147-164.

Marshall, J., Smith, S. \& Buxton, S. (2009). 'Learning Organisation and Organisation learning: What Have We Learned?,' Management Services, Summer, 36-44.

Marsick, V. J. \& Watkinson, K. E. (1999). "Looking Again at Learning in the Learning Organization: A Tool that Can Turn into a Weapon!," The Dimensions of the Learning Organisation, 6(5), 207-211.

Mohd Shamsul, M. S., Norliya, A. K. \& Mohd Idzwan, M. S. (2011). 'Organisational Learning Capabilities (OLC) towards Knowledge Performance of Librarians : A Research Model,' Proceedings of the 8th International Conference on Intellectual Capital, Knowledge Management and Organisational Learning (ICICKM), ISBN 978-1-1-908272-20-1, 27-28 October 2011, Bangkok, Thailand, 771-778.

Norliya, A. K. \& Abdullah, K. A. S. (2012). 'Learning Organization in Libraries: Experiences in Malaysia and Yemen,' Shah Alam: UiTM Press, UiTM.

Pearce, J. A. \& David, F. (1987). "Corporate Mission Statement: The Bottom Line," Academic Management Executive, 1(2), 109-116.

Poon, June M. L. \& Kamarul Zaman, M. A. (1998). 'Characteristics and Dimension of a Learning Organisation: An Exploratory Study,' Malaysian Management Review, 33(2). 
11 Journal of e-Learning \& Higher Education

Rowley, J. (2000). "Is Higher Education Ready for Knowledge Management?," The International Journal of Educational Management, 14(7), 325-333.

Selden, G. L. (1998). 'Family Business as Learning Organizations: An Explanatory Model of Knowledge and Financial Performance,' Ph.D. Dissertation, University of Georgia, Athens, Georgia V. J.

Senge, P. M. (1990). "The Leader's New Work: Building Learning Organisations," Sloan Management Review, Fall, 7-23. 